AGRICULTURE AND BIOLOGY JOURNAL OF NORTH AMERICA

ISSN Print: 2151-7517, ISSN Online: 2151-7525, doi:10.5251/abjna.2013.4.1.48.53

(C) 2013, ScienceHuß, http://www.scihub.org/ABJNA

\title{
Study the impact of Trichoderma harzianum filtrate on vitality of some hard wheat seeds, and on their interior associated fungi.
}

\author{
${ }^{1}$ Hamitou Mokhtar and ${ }^{2}$ Aid Dehimat \\ ${ }^{1}$ Department of Nature and Life Sciences, faculty of exact sciences and nature and life \\ Sciences, University of Larbi Ben Mehidi, Oum-elbouaghi, Algeria. \\ ${ }^{2}$ Department of Biochemistry and Microbiology, Faculty of nature and life Sciences, \\ University of Mentouri, Constantine, Algeria
}

\begin{abstract}
The aim of this study is to clarify the effect of the treatment with Trichoderma harzianum filtrate on vitality of some hard wheat seeds and on their interior associated fungi. Three samples of hard wheat seeds (Triticum durum Desf) were brought from Oum-elbouaghi (Algeria) silos yields, follower for varieties: Vitron, Waha, and GTA.Seed treatment with Trichoderma harzianum filtrate showed: 1-An increase in the proportion of seed germination in Waha and in GTA with ratios equal to: $0.47 \%$ and $05.56 \%$ in two cultivars respectively, compared to untreated seeds (controls).Moreover, improvement in growth and strength of seedlings were clearly evident in three treated cultivars compared to untreated seeds (control), where those which their growth was low, and some deformation and anomalies were clearly evident. 2- A strong decrease in the interior associated fungi numbers, with ratios equal to: $74.074 \%$, $79.166 \%$, and $93.75 \%$ in: Vitron, GTA, and Waha respectively, compared with untreated seeds (controls).
\end{abstract}

Key words: variety, GTA, filtrate, Trichoderma harzianum, seedlings.

\section{INTRODUCTION}

Wheat (Triticum durum Desf.) is one of the most important cereal crops in the world and grown in all areas of Algeria. Wheat seeds are a favorable medium for the pathogenic mycoflore and carrying them, those fungi cause a decrease in both seed vitality, and nutritional value, moreover the excretion of mycotoxins (12). Alternaria genus contains a great number of species plus of sixty, parasites or saprophytes, there effect announced on seeds; Alternaria parasites are the origin of the germination lacks, sowing dissolution and there are significant inoculum sources of the adult plants (16). In pathogenicity study of five Fusarium spp frequently isolated from wheat and barley roots in the southern Idaho during growth-chamber experiments and field studies showed that the presence of Fusarium culmorum from infected root tissue, followed by F.acuminatum and $F$. reticulatum, however F.semitectum,followed by F.acuminatum and F.equiseti had the greatest impact on total root length(4). Trichoderma viride and T.harzianum were used in the control against the associated fungi with seeds, including Aspergillus flavus and Fusarium moniliforme; also they were used as anti-fungal against Lasiodiplodia theobroma, Diplodia natalensis, Botryodiplodia theobromae, Rhizoctonia sp,
Aspergillus niger, A.tamarii, Penicillium oxalicum, and P.sclerotinum [(3),(19),(18),(13),(14)] Trichoderma spp, are free-living fungi that are common in soil and root ecosystems, they are highly interactive in root, soil and foliar environments. They produce or release a variety of compounds that induce localized or systemic resistance responses in plants, Trichoderma strains have long been recognized as biological agents, for the control of plant disease and for their ability to increase root growth and development, crop productivity, resistance to abiotic stresses, and uptake and use of nutrients (15).

In this investigation, three samples of hard wheat seeds (Triticum durum Desf) were brought from Oum-elbouaghi (Algeria) silos yields, follower for varieties: Vitron, Waha, and GTA, for evaluated the impact of Trichoderma harzianum filtrate on seeds vitality and on their interior associated fungi.

\section{MATERIALS AND METHODS}

Wheat seeds: Three sample of local solid wheat seeds (Triticum durum Desf) were brought from Oum-elbouaghi (Algeria) silos yields, follower for varieties: GTA, Vitron, and Waha). They were stored for one year. (Fig.1a) 
Measure the seeds vitality: To determine percentage germination of the wheat seeds, 200 seeds of each varieties were germinated between moist paper with sterilized distilled water, and plated (15 seeds per plate )at $22^{\circ} \mathrm{C}$, and seedlings were counted at four and seven days (12).

Fungus material: A sample of antagonist Trichoderma harzianum / Hypocrea lixii was isolated from the soil of wheat plant and identified in Laboratory of Microbiology,( University of Oumelbouaghi, Algeria) [(2),(17), (1),(6)]. And verified by Professor Thonart Philippe, Microbial biotechnology, Walloon Center of Biology Industrial, University of Liege, Belgium.

Preparation of Trichoderma harzianum filtrate : four mycelial disc $(1 \mathrm{~cm}$ in the diam.) of Trichoderma harzianum isolate were obtained from 4-5 days-old culture and transfered to $50 \mathrm{ml}$ of Potato-Dextrose medium containing: (Potato-extract $=200 \mathrm{~g}$, Glucose $=20 \mathrm{~g}$, Distilled water=11. After heat sterilization for $20 \mathrm{~min}$ at $115^{\circ} \mathrm{C}$ ) in a $250-\mathrm{ml}$ conical flask separately and incubated at $27^{\circ} \mathrm{C}$, for 21 days with shaken every day. At the end of the incubation period the resulting then was filtered through sterilized filter paper (Wattman $n^{\circ} 1$ ). After filtering, the Trichoderma filtrate was taken while the mycelium was rejected [(5), (9)].

Seed Treatment with Trichoderma filtrate: 400 seeds of each variety were sterilized with $10 \%$ sodium hypochlorite solution for $2 \mathrm{~min}$, rinsed trice with sterilized distilled water, and dried with sterile filter paper. After that the seeds of each variety were divided into two groups:

1-200 seeds of each variety were soaked for $1 \mathrm{~h}$ in Trichoderma filtrate.

2-200 seeds of each variety were soaked for $1 \mathrm{~h}$ in sterilized Potato-dextrose medium as control. The seeds were plated in sterilized plastic Petri plates (15 seeds per plate) between moist sterilized papers with sterilized distilled water, at $22^{\circ} \mathrm{C}$ in the dark, each experiment included four replicates. Germination was measured every $12 \mathrm{~h}$ and seeds counted as germinated when the radicle protruded through the seed coat. The numbers of surviving seedlings were counted with controlled the borne fungi on the seeds over seven days. The fungi were identified on the basis of their morphological and reproductive characters [(12), (5), (9), (2), (17), (1)].

After seed germination, the Petri dishes were transferred in culture chamber at $22^{\circ} \mathrm{C} \pm 2^{\circ} \mathrm{C}$ with 10 $\mathrm{h}$ of light and seedlings were irrigated with Knops solution over 21 days(7).

\section{RESULTS}

Seeds vitality: Seed treatment with Trichoderma harzianum filtrate showed an increase in the proportion of germination in Waha and in GTA with ratios equal to: $0.47 \%$ and $05.56 \%$ in two cultivars respectively, compared to the controls. Moreover, improvement in growth and strength of seedlings were clearly evident in three cultivars compared to untreated seeds (control), where those which their growth was low, and some deformation and anomalies were clearly evident.[(Table 1) and (Fig 1b)].

Influence of the Trichoderma filtrate on the apparition of interior associated fungi with seeds: Seed treatment with Trichoderma harzianum filtrate showed a strong decrease in the numbers of interior associated fungi, with ratios equal to: $74.074 \%$, $79.166 \%$, and $93.75 \%$ in : Vitron, GTA, and Waha respectively, compared with untreated seeds (controls).[ (Table 1) and (Fig.2)]. Moreover, the treatment with Trichoderma filtrate protected the seedlings against infection with associated fungi during the experiment days, especially in waha variety, compared with untreated seeds where the molds prevailed on the seedlings after germination and continued their prevalence on it during the experiment. ( Fig.3) 
Table.1: Seed percentage germination and interior companying fungi from treated wheat seeds with Trichoderma filtrate compared with non-treated seeds.

\begin{tabular}{|c|c|c|c|c|c|c|c|}
\hline \multirow{2}{*}{$\begin{array}{l}\text { Seeds } \\
\text { variety }\end{array}$} & \multirow{2}{*}{$\begin{array}{l}\text { Treatment } \\
\text { With Trichoderma } \\
\text { filtrate }\end{array}$} & \multirow{2}{*}{$\begin{array}{c}\% \text { of } \\
\text { germin- } \\
\text { ation } \\
\text { before } \\
\text { experiment }\end{array}$} & \multirow{2}{*}{$\begin{array}{c}\% \text { of } \\
\text { germin- } \\
\text { ation } \\
\text { after } \\
\text { experiment }\end{array}$} & \multicolumn{3}{|c|}{$\begin{array}{c}\text { Fungus genus with its isolate } \\
\text { number's }\end{array}$} & \multirow{2}{*}{$\begin{array}{c}\text { Total } \\
\text { Number } \\
\text { of } \\
\text { isolates }\end{array}$} \\
\hline & & & & $\begin{array}{c}\text { Alternaria } \\
\text { sp }\end{array}$ & $\begin{array}{c}\text { Fusarium } \\
\text { sp }\end{array}$ & $\begin{array}{l}\text { Rhizopus } \\
\text { sp }\end{array}$ & \\
\hline \multirow{2}{*}{ GTA } & Non-treated & 91 & 92 & 17 & 5 & 2 & 24 \\
\hline & Treated & 91 & 97.56 & 5 & 0 & 0 & 5 \\
\hline \multirow[b]{2}{*}{ Vitron } & $\begin{array}{l}\text { Non- } \\
\text { treated }\end{array}$ & 92 & 91.66 & 26 & 1 & 0 & 27 \\
\hline & Treated & 92 & 86.66 & 7 & 0 & 0 & 7 \\
\hline \multirow[t]{2}{*}{ Waha } & $\begin{array}{l}\text { Non- } \\
\text { treated }\end{array}$ & 90 & 92.86 & 10 & 2 & 4 & 16 \\
\hline & Treated & 90 & 93.33 & 1 & 0 & 0 & 1 \\
\hline
\end{tabular}

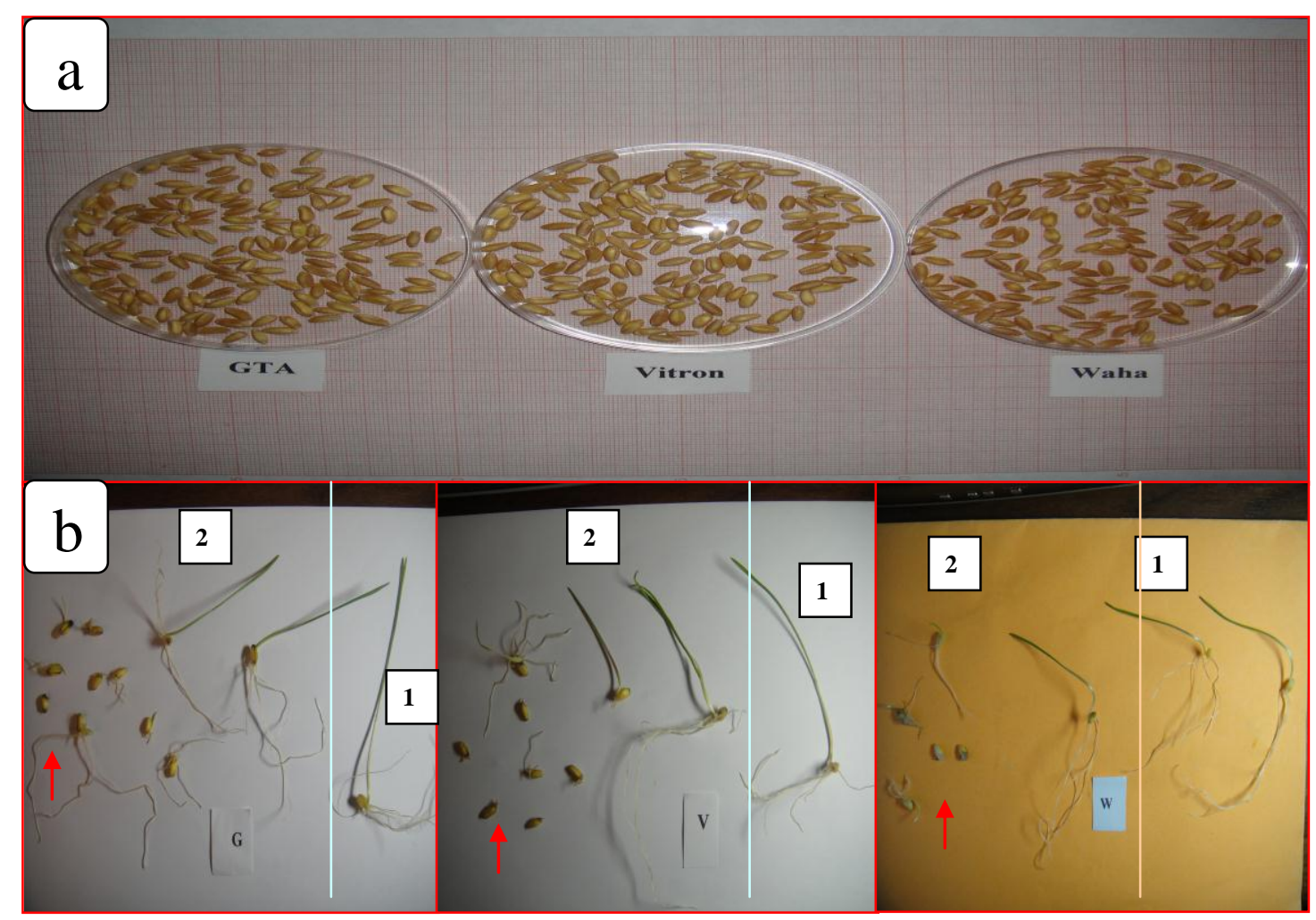

Fig.1: a -Wheat seeds varieties used in experiment. $b$ - Wheat seedlings after germination. G = GTA, V=Vitron, W=Waha.1= Treated seedlings with Trichoderma filtrate, 2=Non-treated seedlings with Trichoderma filtrate (red arrows )= Indicate the contamination with fungi and some deformation and anomalies. 
Agric. Biol. J. N. Am., 2013, 4(1): 48-53
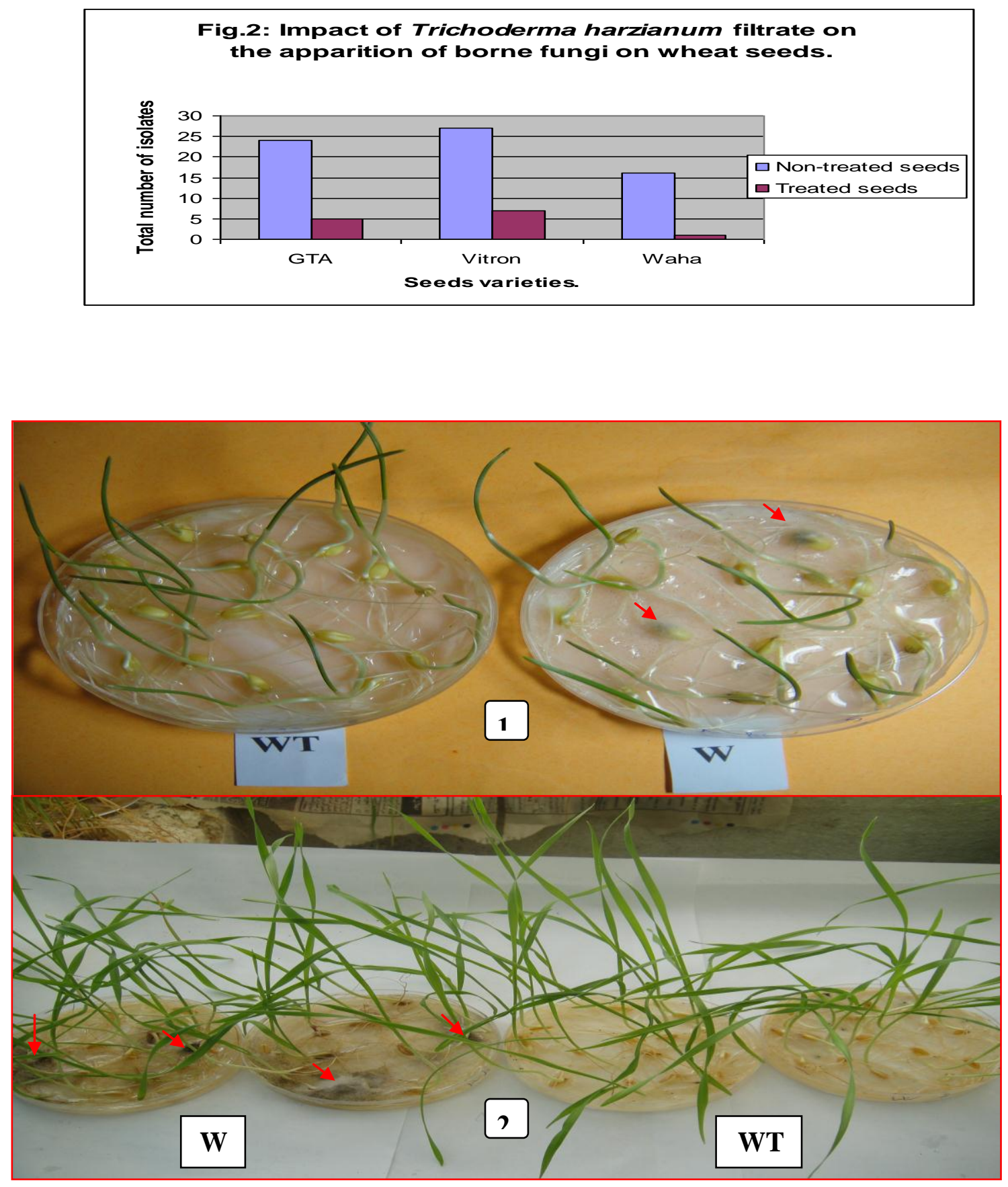

Fig.3: waha seedlings after germination.1=Plants aged 10 days.2=Plants aged 20 days.W=Plants non-treated with Trichoderma filtrate. (Red arrows)= Signify the contamination with fungi. WT=Plants treated with Trichoderma filtrate. 


\section{DISCUSSION}

Influence of the Trichoderma filtrate on seeds vitality and, on the apparition of interior associated fungi on wheat seeds and seedlings:

Seed treatment with Trichoderma harzianum filtrate showed an increase in the proportion of germination in Waha and in GTA, and a strong decrease in the numbers of interior associated fungi in Waha, GTA and Vitron, moreover protected the seedlings after germination against infection with molds during the experiment days. This results was confirmed by experiment results of Hamed and al, (2011)(8) In order to investigate effect of Trichoderma harzianum $\mathrm{Bi}$ on seed germination and seedling quality and field establishment of two muskmelon cultivars, Khatooni and Qasri, the results show that the Trichoderma application significantly increased germination and emergence percentage and index and could help improving seedling health and vigor.STP was significantly affected by Trichoderma application and $1^{\text {st }}$ method of application had better results. Also Lifshitz and al (1986)(10), found that the Application of conidia of isolates of Trichoderma harzianum or Trichoderma koningii to pea seed reduced the incidence of preemergence damping-off of peas induced by a Phythium sp, germination of sporangia of the Phythium $s p$, or chlamydospores of Fusarium oxysporium f.sp.cucumerinum in the spermospherev of peas treated with the isolates of Trichoderma was comparable to that of nontreated controls. Also the common bean roots were treated with $T$. harzianum ( $T$ 1) and $T$. asperellum (T-2) individually and in combination with each other and planted in artificially infested soil with $F$. solani pathogen, Our findings indicated that prepared conidial suspensions either in water and $10 \%$ sugar solution effectively are able to reduce the colonization of the $F$. solani, (Mohammad and al, 2012). (11). Also the chili seeds were coated with spore suspension of $T$. virens IMI-392430, $T$. pseudokoningii IMI-392431, T. harzianum IMI-392432, $T$. harzianum IMI-392433 and $T$. harzianum IMI392434, the results showed that the seed germination percentages and the vigour index were significantly $(P \leq 0.05)$ affected by the application of different strains of Trichoderma, and the Chili seeds also gave the highest vigour index values with $T$. harzianum IMI3924332 which confirmed to better germination, (Islam and al, 2011).(9).

These results showed that a high efficacy of this local isolate of Trichoderma harzianum, against the appearance of interior associated fungi on wheat seeds and, showed an increase in the proportion of seed germination in Waha and in GTA, moreover protected the wheat seedlings after germination against infection with molds during the experiment days.

This study strongly suggests that this Trichoderma harzianum isolate can be exploited for the biological control of seed diseases at the field level.

\section{REFERENCES}

1. Booth, C.1977. Fusarium laboratory guide to the identification of the Major species .Common wealth Mycological Institute. England.58p.

2. Botton,B.,Breton,A.,Fevre,M.,Gauthir,S.,Larpent,J.P.,G ay,P.H., Reymond,P.,Sanglier,J.J.,VayssierY.and Veau,P.1990. Moisissures utiles et nuisible importance industrielle 2 ème $\mathrm{Ed}$.Masson, Paris. Milan, Barcelone, Mexico, 512pp.

3. Calistru, C., M.McLean, .P.Berjak.1997.In vitro studies on the Potential for biological control of Aspergillus flavus and Fusarium moniliforme by Trichoderma species1. Macro- Scopical and microscopical observations of fungal interactions Mycopathologia.139:115-121.

4. Carl, A.Strausbaugh., Ken, Overturf., and Anita, C.Koehn.2005.Pathogenicity and real-time PCR detection of Fusarium spp.in wheat and barley roots.Can.J.Plant Pathol.27:430-438.

5. Charles, R. Howel.2007. Effect of Seed Quality and Combination Fungicide-Trichoderma spp.Seed Treatments on Pre- and Postemergence Damping-Off in Cotton, Charles R. Howell, Phytopathology, 97, 1:66-71.

6. Christian, P.Kubicek and Gary, E. Harman. 2002. Trichoderma and Gliocladium, Volume 1. Basic biology, taxonomy and genetics. Taylor \& Francis eLibrary.293p.

7. Haider, M.M., E.D.Soulaiman. and R.K. Dawwood. 1986. Effect of Culture filtrate of five species of fungi and their mixture On seed germination and seedling development of Sunflower.J.Bio Sci.Reas.

8. Hamed, Kaveh., Safieh, Vatandoost . Jartoodeh., Hossein, Aruee and Morteza, Mazhabi.2011. Would Trichoderma Affect Seed Germination and Seedling Quality of Two Muskmelon Cultivars, Khatooni and Qasri and Increase Their Transplanting Success. J. Biol. Environ. Sci., 5(15), 169-175.

9. Islam, M.S., M.A, Rahman, S.H, Bulbul., and M.F, Alam. 2011. Effect of Trichoderma on seed germination and seedling parameters in Chili. Int. J. Expt. Agric. 2(1):21-26

10.Lifshitz, R., M.T.Windham, and Ralph, Baker.1986.Mechanism of biological control of preemergence damping-off of pea by seed treatment 
with Trichoerma spp. Ecology and Epidemiology. Phytopathology. 76(7):720-725.

11. Mohammad, Akrami., Mohsen, Sabzi., Farhad, Baghbani, Mehmandar, and Ehsan, Khodadadi. 2012. Effect of seed Treatment with Trichoderma harzianum and Trichoderma asperellum species for controlling Fusarium rot of common bean, Annals of Biological Research, 3 (5):2187-2189.

12. Moreno, M.E. and G.Vidal-Gaona.1986.Preserving the viability of Seed with fungicides. Plant Disease, 65:260-261.

13. Moreno, L.S., R.A.Paningbatan.1995.Biological control of mango Stem-end rot caused by Diplodia natalensis with Trichoderma Viride .Philippine Phytopathol.31:103-116.

14. Mortuza, H.G., L.L.llag.1999.Potential for biocontrol of Lasiodiplodimaea theobro (Pat) Griff.and Maubl.in banana fruits by Trichoderma species.Biol.Control.15:235-240.
15. Ranasingh, N., A, Saurabh., and M, Nedunchezhiyan. 2006. Orrissa Review.68-70.

16.Rémi, Champion.1997.Identifier les champignons transmis par les semences. INRA. France, 399p.

17. Robert, A. Samson., Ellen, S. Hoekstra. And Connie, A.N.Vanoorschot. 1981. Introduction to -Food-borne Fungi C.B.S, Institute of the Royal Netherlands. Academy Arts and Sciens.

18. Okigbo, R.N., F.E.Oikediugwu. 2000. Studies on biological control of post harvest rot in yams Dioscorea spp using Trichoderma viride. J.Phytopathol.148:259263.

19. Thangavelu, R., A.Palaniswami., R.Velazhahan. 2004. Mass production of Trichoderma harzianum for managing fusarium wilt of banana. Agric. Ecosys. Environ.103:259-263. 